\title{
Effect of lipid level in a compound diet on the development of red drum (Sciaenops ocellatus) larvae
}

\author{
V. Buchet ${ }^{\mathrm{a}}$, J. L. Zambonino Infante ${ }^{\mathrm{b},{ }^{*}}$ and C. L. Cahu ${ }^{\mathrm{b}}$ \\ a IFREMER, Pointe Fort, 97231 Le Robert, Martinique, France \\ ${ }^{\mathrm{b}}$ Unité Mixte de Nutrition des Poissons, INRA-IFREMER, B.P. 70, 29280 Plouzané, France \\ *: Corresponding author : Tel.: +33-298224090; fax: +33-298224653; e-mail: jlzambon@ifremer.fr
}

\begin{abstract}
:
Red drum larvae were fed, from day 11 to day 24 post-hatch, with Artemia (LP group) or two isoproteinic-formulated diets with varying lipid levels, 15\% (L15 group) and 30\% (L30 group). The lipid fraction was composed of a mixture of cod liver oil and soy lecithin. Larvae fed Artemia exhibited the greatest length; L30 diet induced a larvae length significantly greater than that obtained with L15 diet $(P<0.05)$. No difference was observed in larvae survival among the three dietary groups. The increase in dietary lipid concentration led to an increase in amylase and trypsin secretion levels in 24-day-old larvae. The pancreatic secretion level measured in L30 group was close to that of LP group, suggesting that the maturation of the pancreatic functions was normally developed. Red drum larvae fed the diet containing the higher lipid content (L30) exhibited a more developed brush border membrane digestion in the intestine than larvae fed L15 diet $(P<0.05)$. Phospholipase A2 was stimulated by the increase of phospholipids in the diet, but no difference was observed for lipase between the two compound diet-fed groups; the LP group exhibited the lowest lipase activity. A plateau in lipase activity may have occurred in red drum larvae from $15 \%$ fat level in the diet, suggesting that the maximal lipase activity was reached with $12 \%$ neutral lipid in the diet. The positive effects observed with high dietary fat may be due to the phospholipid fraction of the lipid mixture used.
\end{abstract}

Keywords: Red drum; Larvae; Lipid; Compound diet; Digestive enzymes; Gut maturation 


\section{Introduction}

Recent studies (Cahu et al., 1998; 1999; Zambonino Infante and Cahu, 1999) have shown that experimental compound diets can totally replace Artemia in the feeding sequence of European sea bass larvae. These experimental diets have been formulated taking into account the specificities of the larval mode of digestion, and allowed sea bass larvae to acquire an adult mode of digestion. The utilization of such compound diets in marine fish hatcheries can now be considered since good larval growth and survival were obtained in the sea bass experiments.

A marine fish species that would greatly benefit by Artemia replacement would be red drum larvae, a warmwater marine fish cultured commercially in the USA and the Caribbean area. Indeed, some authors have already obtained promising results by feeding red drum larvae with experimental or commercial feeds (Holt, 1993; Brinkmeyer and Holt, 1998). Moreover, Buchet et al. (1997) reported that red drum larvae acquired an efficient mode of digestion at least one week earlier than European sea bass larvae.

Considering these data, it is likely that the experimental diets efficient for European sea bass would also be adequate for red drum larvae, even if some differences in the nutritional requirements of the two species are noted in the literature. Zambonino Infante and Cahu (1999) have demonstrated an improvement of larval development of European sea bass when fed high dietary lipid levels (higher than 25\%); on the other hand, Brinkmeyer and Holt (1995) reported that a moderate lipid level (18\%) in the diet was more appropriate for red drum larval development.

The aim of the present experiment was to determine the effects of two different dietary lipid levels (15 and 30\%) on maturation of the digestive functions and larval development of red drum, by using experimental compound diets successfully tested in European sea bass larvae.

\section{Material and methods}

\subsection{Animals and diets.}

Larval rearing of red drum (Sciaenops ocellatus) was conducted at the Ifremer-Station de Martinique and lasted 24 days. Newly hatched larvae were transferred from incubators to 9 cylindro-conical fiber glass tanks (40 l, initial stocking density: 100 larvae $\cdot \mathrm{l}^{-1}$ ). They were supplied with running seawater which had been filtered through a $10 \mu \mathrm{m}$ filter, then passed through an ultraviolet sterilization unit. Throughout the experiment, the water temperature and salinity were $28.5-32^{\circ} \mathrm{C}$ and $27 \mathrm{~g} \cdot \mathrm{l}^{-1}$, respectively. Constant aeration was maintained through an air stone. Photoperiod was set at $12 \mathrm{~h}$ light:12 h dark.

The larvae were fed Brachionus plicatilis from mouth opening until day 10. Then the larvae were divided into 3 groups (3 tanks per group) and fed for 13 days with Artemia (LP for Live Prey group) or two isoproteinic formulated diets (L15 and L30: Table 1) with two increasing fat levels (15-30\%) and decreasing carbohydrate level (14-0\%). From day 10 until day 12, all groups were progressively substituted for Brachionus plicatilis. Artemia (Utah) were used as 1 day old metanauplii, and were enriched with Superselco. The size of the microparticulate diets was 125-200 $\mu \mathrm{m}$ during the first 5 days then 200-400 $\mu \mathrm{m}$. Fish were manually fed 10 times a day (between 0600 and 1800) in excess (2 g at day 10 to $10 \mathrm{~g}$ at day 23 per tank). Food ingestion was monitored by observing the larval digestive tract under a binocular microscope. 
Table 1. Composition of the experimental diets

\begin{tabular}{|c|c|c|}
\hline $\begin{array}{l}\text { Ingredients (g·100 g dry diet } \\
\end{array}$ & L15 & L30 \\
\hline $\begin{array}{l}\text { Fish meal }^{1} \\
\quad(82 \% \text { protein, } 12 \% \text { lipid) }\end{array}$ & 54 & 54 \\
\hline $\begin{array}{l}\text { Hydrolyzed fish meal }^{1} \\
\text { (72\% protein, 20\% lipid) }\end{array}$ & 14 & 14 \\
\hline Vitamin mixture ${ }^{2}$ & 8 & 8 \\
\hline Mineral mixture ${ }^{3}$ & 4 & 4 \\
\hline Betaine & 1 & 1 \\
\hline Cod liver oil ${ }^{1}$ & 2.94 & 10.6 \\
\hline Soy lecithin ${ }^{1}$ & 2.36 & 8.4 \\
\hline Precooked potato starch ${ }^{1}$ & 13.7 & 0 \\
\hline \multicolumn{3}{|l|}{ Proximate composition (\%) } \\
\hline Proteins (Nx6.25) & 57.8 & 56.9 \\
\hline Lipids $^{5}$ & 15.3 & 29.9 \\
\hline Neutral lipids ${ }^{6}$ & 11.8 & 23.2 \\
\hline Phospholipids $^{6}$ & 3.6 & 6.8 \\
\hline Ash & 9.5 & 10.4 \\
\hline Energy $\left(\mathrm{kJ} \cdot \mathrm{kg}^{-1}\right)^{4}$ & 1.67 & 1.95 \\
\hline
\end{tabular}

1 Dietary ingredients were commercially obtained. Fish meal, Hydrolyzed fish meal (CPSP G, Concentré de Protéines Solubles de Poisson) and cod liver oil were from La Lorientaise (Lorient, France). The soy lecithin was from Ets Louis François (St Maur des Fossés, France). The potato precooked starch (Nutralys) was from Roquette (Lille, France).

${ }^{2}$ Per kg of vitamin mix: retinyl acetate $1 \mathrm{~g}$; cholecalciferol $2.5 \mathrm{mg}$; allrac- $\alpha$-tocopheryl acetate $10 \mathrm{~g}$; Na menadione bisulfate $1 \mathrm{~g}$; thiamin 1 g; riboflavin $0.4 \mathrm{~g}$; D- calcium pantothenate $2 \mathrm{~g}$; pyridoxine $\mathrm{HCl} 0.3$ g; cyanocobalamin $1 \mathrm{~g}$; niacin $1 \mathrm{~g}$; choline chloride $200 \mathrm{~g}$; ascorbic polyphosphate (25\%) $20 \mathrm{~g}$; folic acid $0.1 \mathrm{~g}$; biotine $1 \mathrm{~g}$; meso-inositol $30 \mathrm{~g}$.

3 Per kg of mineral mix: $\mathrm{KCl} 90$ g; KI 40 mg; $\mathrm{CaHPO}_{4} 2 \mathrm{H}_{2} \mathrm{O} 500$ g; $\mathrm{NaCl} 40$ g; $\mathrm{CuSO}_{4} \cdot 5 \mathrm{H}_{2} \mathrm{O} 3$ g; $\mathrm{ZnSO}_{4} \cdot 7 \mathrm{H}_{2} \mathrm{O} 4 \mathrm{~g} ; \mathrm{CoSO}_{4} \cdot 7 \mathrm{H}_{2} \mathrm{O} 20$ mg; $\mathrm{FeSO}_{4} \cdot 7 \mathrm{H}_{2} \mathrm{O} 20 \mathrm{~g} ; \mathrm{MnSO}_{4} \cdot \mathrm{H}_{2} \mathrm{O} 3 \mathrm{~g} ; \mathrm{CaCO}_{3} 215 \mathrm{~g} ; \mathrm{MgSO}_{4} \cdot 7 \mathrm{H}_{2} \mathrm{O} 124$ g; $\mathrm{NaF} 1 \mathrm{~g}$.

${ }^{4}$ Calculated as: total carbohydrate x $16.7 \mathrm{~J} / \mathrm{kg}$; fat x $37.7 \mathrm{~J} / \mathrm{kg}$; protein $\mathrm{x} 16.7 \mathrm{~J} / \mathrm{kg}$.

5 Determined according Folch et al. (1957).

6 Determined according Juaneda and Roquelin (1985). 


\subsection{Sampling and dissection.}

To monitor growth, 30 larvae were removed on day 2, 7, 10, 17 and 24 from each tank and the larvae standard length was measured. At the end of the experiment, larval survival in each tank was determined by counting individuals.

At day 24, 50 larvae were collected from each tank before morning food distribution for enzymatic studies. Larvae were immediately frozen and stored at $-80^{\circ} \mathrm{C}$ pending dissection and assays. Dissection under microscope was conducted on a glass maintained at $0^{\circ} \mathrm{C}$. For each larva, the intestine was extracted with a microsurgerical plier (Dumont Moria, ref MC40). The pancreatic segment, including pancreas, liver, heart, muscle and spine, was obtained as described in Cahu and Zambonino Infante (1994).

\subsection{Analytical methods.}

The pancreatic segments were homogenized into 5 volumes $(\mathrm{v} / \mathrm{w})$ of ice-cold distilled water. Trypsin (EC 3.4.21.4) and amylase (EC 3.2.1.1) activities were assayed according to Holm et al. (1988) and Métais and Bieth (1968), respectively. Phospholipase A2 (PLA2; EC 3.1.1.4) was assayed by the reverse-phase high-performance liquid chromatographic method of Tojo et al. (1993). Lipase (EC 3.1.1.3 ) was assayed according Iijima et al. (1998). Purified brush border membranes from the intestinal segment homogenate were obtained according to a method developed for intestinal scraping (Crane et al. 1979). The degree of purification of brush border membrane, taking aminopeptidase $\mathrm{N}$ as marker of cell membrane fraction, was close to that reported by Crane et al. (1979), i.e. 10 fold. The brush border membrane enzyme, aminopeptidase N (EC 3.4.11.2), was assayed according to Maroux et al. (1973). Assay of a cytosolic peptidase, leucine-alanine (leu-ala) peptidase was performed using the method of Nicholson and Kim (1975). Enzyme activities are expressed as specific activities, i.e. mU · mg protein $^{-1}$ or segmental activities, i.e. the total activity of each enzyme per larvae in the pancreatic or intestinal segment. Pancreatic secretion and ratios of enzyme activities of brush border membrane related to leu-ala peptidase activity were calculated using the segmental activities. Protein was determined by the Bradford procedure (Bradford, 1976).

\subsection{Statistical analyses.}

Results are given as mean \pm S.D. $(n=3)$. Percent survival and ratios of segmental enzymatic activities were $\arcsin \left(\mathrm{x}^{1 / 2}\right)$ transformed. The variance homogeneity of the data was checked using Bartlett's test (Dagnelie, 1975). Length, survival rate and ratios of enzymatic segmental activity data were compared by a one-way ANOVA followed by Newman Keuls multiple range test (Dagnelie, 1975) when significant differences were found at the 0.05 level.

\section{Results}

The larvae fed LP diet exhibited the greatest length at day 24 (Fig. 1). This length was 25 and 32\% greater than that of larvae fed L30 and L15 diets, respectively. The L30 diet induced a larvae growth significantly greater than that obtained with the L15 diet. No difference was observed in larvae survival among the three dietary groups at day 24 (Table 2).

The assays of amylase at day 24 in the pancreatic segment are summerized in the Table 2 . The L15 group had an amylase specific activity which was twice that of the LP and L30 groups. . The ratio of enzyme in the intestinal segment over enzyme in the pancreatic plus intestinal segment" reflects the secretion level of the pancreatic enzymes. The secretion of amylase and trypsin (Table 2) were more elevated in the L30 group compared to the L15 group (+57 and $+69 \%$, 
respectively). No difference was observed in amylase secretion between the LP and L30 groups, when trypsin secretion was $45 \%$ higher in the LP group compared to the L30 group.

The highest PLA2 specific activity was found in the L30 group at day 24 (Table 2): this activity was around $75 \%$ more elevated than the L15 and LP groups. Lipase activity was similar in the L15 and L30 groups (Table 2). Larvae fed the compound diets exhibited a lipase activity two times higher than that assayed in larvae fed live prey.

Segmental activity ratios of a brush border enzyme, aminopeptidase N, versus a cytosolic enzyme, leu-ala peptidase, is shown in Table 2. The highest ratios were observed in both the LP and L30 groups. The L15 group exhibited a ratio 20\% lower than the L30 group.

Figure 1 Length of red drum larvae fed the three experimental diets. Means $\pm S D(n=3)$ with different superscript letter are significantly different $(\mathrm{P}<0.05)$.

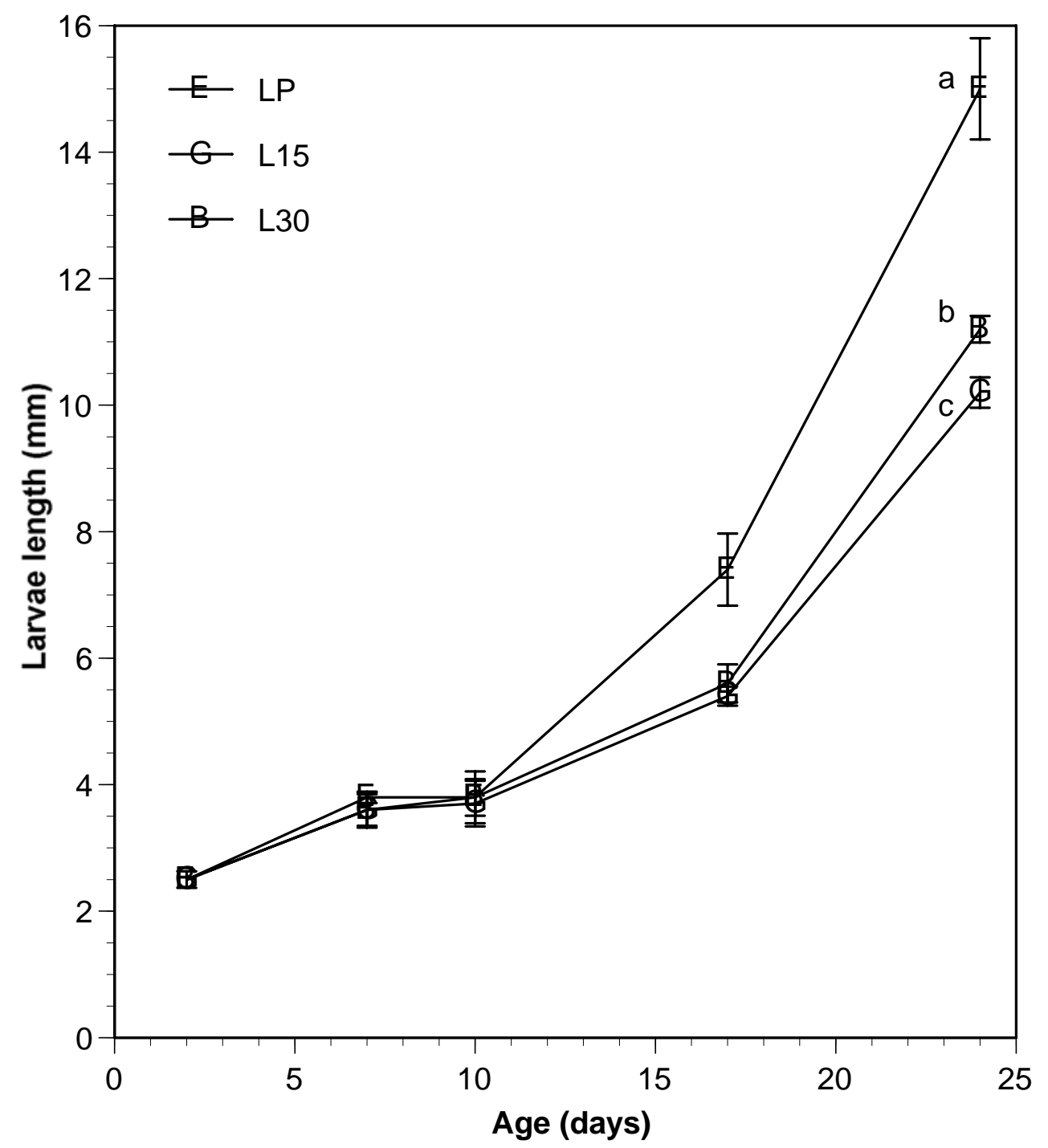


Table 2. Percent survival and enzymatic data of 24 day old red drum larvae fed the three experimental diets. Means \pm S.D. $(n=3)$ with different superscript letter in a row are significantly different $(\mathrm{P}<0.05)$.

\begin{tabular}{|c|c|c|c|c|}
\hline & & $\mathbf{L P}$ & L15 & L30 \\
\hline Survival (\%) & & $20.3 \pm 3.97$ & $20.3 \pm 2.03$ & $21.3 \pm 1.88$ \\
\hline Amylase & $\mathrm{U} / \mathrm{mg}$ protein & $1.4 \pm 0.31 b$ & $2.9 \pm 0.76 a$ & $1.4 \pm 0.19 b$ \\
\hline \multicolumn{5}{|c|}{ Pancreatic secretion (in \%) } \\
\hline Amylase & & $75 \pm 3.8 \mathrm{a}$ & $44 \pm 0.80 b$ & $69 \pm 7.0 \mathrm{a}$ \\
\hline Trypsin & & $32 \pm 5.4 a$ & $13 \pm 1.0 \mathrm{c}$ & $22 \pm 2.5 b$ \\
\hline Phospholipase A2 & $\mathrm{mU} / \mathrm{mg}$ protein & $2.3 \pm 0.21 b$ & $2.0 \pm 0.66 b$ & $3.5 \pm 0.06 a$ \\
\hline Lipase & $\mathrm{mU} / \mathrm{mg}$ protein & $0.6 \pm 0.12 b$ & $1.3 \pm 0.40 \mathrm{a}$ & $1.3 \pm 0.32 \mathrm{a}$ \\
\hline \multicolumn{2}{|c|}{$\begin{array}{l}\text { Aminopeptidase N/leu-ala peptidase } \\
\qquad\left(\times 10^{5}\right)\end{array}$} & $3.9 \pm 0.34 \mathrm{ab}$ & $3.3 \pm 0.29 b$ & $4.1 \pm 0.33 \mathrm{a}$ \\
\hline
\end{tabular}

\section{Discussion}

During this experiment, red drum larvae were able to ingest the microparticulate diets as early as the $10^{\text {th }}$ day post-hatching. Valid nutritional observations can be drawn from this study since a three fold increase in larvae length has been observed between day 10 and day 24. Moreover, the lengths obtained in our study were generally greater than those reported for red drum fed artificial diets (Holt and Sun, 1991; Brinkmeyer and Holt, 1998).

The increase in dietary lipid level from 15 to $30 \%$ led to a $10 \%$ increase in larvae standard length, suggesting that high energy diets are needed during larval stages as previously observed for European sea bass larvae (Zambonino Infante and Cahu, 1999). Brinkmeyer and Holt (1995) fed red drum larvae diets containing menhaden oil levels ranging from 13 to $27 \%$ and found that the 18\% lipid diet induced the best larvae growth. The different components of the lipid mixtures used in the two studies may explain these two different findings.

The survival of larvae fed the compound diets was not affected by the dietary lipid level. The observed survival was similar to that of larvae fed live prey, i.e. $21 \%$; this result constituted an important advance compared to the $12-15 \%$ survival reported in the literature for red drum larvae fed a commercial diet (Brinkmeyer and Holt, 1995).

The incorporation of $14 \%$ starch in the L15 diet led to an increase in amylase specific activity in pancreas of larvae fed this diet, compared to the two other groups. Adaptation of amylase activity to dietary starch content has been extensively reported in mammals (see Sheele, 1993) and more recently in marine fish larvae (Cahu and Zambonino Infante, 1994). Péres et al. (1998) have shown that the increase in amylase activity globally resulted from an increase in amylase mRNA in European sea bass larvae. These authors also suggested a translational regulation of amylase synthesis, and hypothesized a possible involvement of hormones in this regulation. Moreover, the large range of amylase modulation could be a sign of a natural trend of young red 
drum larvae to use carbohydrates. Péres et al. (1996) have demonstrated that a moderate supply of dietary carbohydrates seemed to be beneficial for European sea bass larvae. Nevertheless, neither for European sea bass larvae (Zambonino Infante and Cahu, 1999) nor for red drum larvae, the incorporation of starch in the compound diet was beneficial for growth and survival within the experimental duration used.

The onset of pancreas secretory functions occurred during the 18 first day of life of red drum larvae (Buchet et al., 1997). It has been shown that the onset of these digestive mechanisms can be delayed or stopped in European sea bass larvae fed an inadequate diet (Cahu and Zambonino Infante, 1994). In our study, the increase of the dietary lipid level led to an increase in amylase and trypsin secretion levels in 24 day old red drum larvae. It should be pointed out that the pancreatic secretion level measured in the L30 group was close to that of the LP group, suggesting that the maturation of the pancreatic functions were normally developed in this group. Though amylase synthesis was efficient in the L15 group, the low amylase secretion in this group suggested a delayed development of pancreatic secretory functions compared to the L30 group. Pancreatic secretion of digestive enzymes is mainly mediated by an intestinal hormone, cholecystokinin (CCK), which is known to be stimulated in rats by the ingestion of fat through a CCK-releasing factor (Liddle, 1995). The existence of such a hormonal mechanism has been also suggested by Zambonino Infante and Cahu (1999) in European sea bass larvae fed diets with increasing levels of lipid. In the same way, the high pancreatic secretion related to high dietary fat content observed in red drum, could suggest the existence of a CCK-releasing factor in this species.

The lipid components of the two experimental diets used in this study were composed of a mixture of cod liver oil (neutral lipids) and soy lecithin (phospholipids). The increase of PLA2 specific activity in red drum larvae with the increase of dietary fat content was the result of a normal stimulation of the enzyme by the increase in substrate, i.e. phospholipids, in the diet. Indeed, this enzymatic response has been extensively reported in mammals (Sheele, 1993) and recently in European sea bass larvae (Zambonino Infante and Cahu, 1999).

Lipase in red drum larvae was not stimulated by the increase of fat content in the compound diets. This finding is surprising since Zambonino Infante and Cahu (1999) have shown an increase of lipase activity in European sea bass larvae from $20 \%$ dietary fat level onwards. In our study, a difference in lipase activity only appeared between larvae fed the LP diet and larvae fed the compound diets. The lower lipase activity assayed in larvae fed live prey could be the result of a lower lipid content (10\%) in Artemia, as reported by Cahu and Zambonino Infante (1995). Taking into account these data, it can be assumed that the plateau in lipase activity occurred in red drum larvae from $15 \%$ fat level in the diet. Such a plateau in lipase activity would sugest that the maximal capacity in lipase synthesis was reached at $15 \%$ dietary fat, i.e. $11.8 \%$ neutral lipids. This would explain why Brinkmeyer and Holt (1995) did not find any positive effect of menhaden oil contents higher than $18 \%$ in diets for red drum larvae. In our experiment, the observed positive effect with high dietary fat may have been due to the phospholipid fraction of the lipid mixture.

Red drum larvae normally acquire a functional intestinal brush border around day 18 posthatching (Buchet et al., 1997). This maturation process occurs by the onset of digestion in brush border membranes of enterocytes, concurrently with the decline of cytosolic digestion (Zambonino Infante et al., 1997). The developmental stage of enterocyte differentiation can be assessed by considering the segmental activity ratio of brush border enzyme, aminopeptidase N, versus a cytosolic enzyme, leu-ala peptidase. This ratio reflects the relative importance of brush border membrane digestion compared to cytosolic digestion at a given developmental stage of marine fish larvae. At day 24, red drum larvae fed the diet containing the higher lipid content (L30) exhibited a more developed membranous digestion than that of larvae fed the L15 diet. 


\section{Conclusion}

The diets, efficient for European sea bass larvae development, also satisfied nutritional requirements of red drum. High lipid level diets, containing elevated phospholipid concentration, positively act on gut maturation and larval development of red drum.

The growth and survival obtained in this study suggest that compound diets could replace live prey in certain marine fish hatcheries in the near future. These compound diets, which composition can be controlled, would allow to produce reliable high quality larvae without cost fluctuations. 


\section{References}

Bradford, M.M., 1976. A rapid and sensitive method for the quantitation of microgram quantities of protein utilizing the principle of protein-dye binding. Anal. Biochem. 72, 248-254.

Brinkmeyer, R.L., Holt, G.J., 1995. Response of red drum larvae to graded levels of menhaden oil in semipurified microparticulate diets. Prog. Fish-Cult. 57, 30-36.

Brinkmeyer, R.L., Holt, G.J., 1998. Highly unsaturated fatty acids in diets for red drum (Sciaenops ocellatus) larvae. Aquaculture 161, 283-268.

Buchet, V., Zambonino Infante, J.L., Cahu, C.L., 1997. Variation in activities of some digestive enzymes during larval development of Sciaenops ocellatus. Island Aquaculture and Tropical Aquaculture, Communications and abstracts Martinique 97-European Aquaculture Society International Conference, Les Trois Ilets, Martinique, 4-9 may 1997, pp 55-56.

Cahu, C.L., Zambonino Infante, J.L., 1994. Early weaning of sea bass (Dicentrarchus labrax) larvae with a compound diet: effect on digestive enzymes. Comp. Biochem. Physiol. 109A, 213-222.

Cahu, C.L., Zambonino Infante, J.L., 1995. Maturation of the pancreatic and intestinal digestive functions in sea bass (Dicentrarchus labrax): effect of weaning with different protein sources. Fish Physiol. Biochem. 14, 431-437.

Cahu, C.L., Zambonino Infante, J.L., Escaffre, A.M., Bergot, P., Kaushik, S., 1998. Preliminary results on sea bass (Dicentrarchus labrax) larvae rearing with compound diet from first feeding. Comparison with carp (Cyprinus carpio) larvae. Aquaculture 169, 1-7.

Cahu, C.L., Zambonino Infante, J.L., Quazuguel, P., Le Gall, M.M., 1999. Protein hydrolysate vs. fish meal in compound diets for 10-day old sea bass Dicentrarchus labrax larvae. Aquaculture 171, 109-119.

Crane, R.K., Boge, G., Rigal, A. 1979. Isolation of brush border membranes in vesicular form from the intestinal spiral valve of the small dogfish (Scyliorhinus canicula). Biochim. Biophys. Acta 554, 264-267.

Dagnelie, P., 1975. Les méthodes de l’inférence statistique. In: Ducolot, J. (Ed.), Théorie et méthodes statistiques. Les Presses Agronomiques de Gembloux, Gembloux, Belgium, vol. 2, pp. 1-463.

Folch, J.M., Lee, M., Stanley, G.N.S., 1957. A simple method for the isolation and purification of total lipids from animal tissues. J. Biol. Chem. 29, 497-509.

Holm, H., Hanssen, L.E., Krogdahl, A., Florholmen, J., 1988. High and low inhibitor soybean meals affect human duodenal proteinase activity differently: in vivo comparison with bovine serum albumin. J. Nutr. 118, 515-520.

Holt, G.J., 1993. Feeding larval red drum on microparticulate diets in a closed recirculating water system. J. World Aquacult. Soc. 24, 225-230. 
Holt, G.J., Sun, F., 1991. Lipase activity and total lipid content during early development of red drum Sciaenops ocellatus. In: Lavens, P., Sorgeloos, P., Jaspers, E., Ollevier, F. (Eds), Larvi'91. Fish and shellfish larviculture symposium, 1991, Gent, Belgium. European Aquaculture Society, Special Publication 15, pp. 30-33.

Iijima, N., Tanaka, S., Ota, Y., 1998. Purification and characterization of bile salt-activated lipase from the hepatopancreas of red sea bream, Pagrus major. Fish Physiol. Biochem. 18, 59-69.

Juaneda, P., Roquelin, G., 1985. Rapid and convenient separation of phospholipids and non phosphorus lipids from rat heart using silica cartridges. Lipids 20, 40-41.

Liddle, R.A., 1995. Regulation of cholecystokinin secretion by intraluminal releasing factors. Am. J. Physiol. 269, G319-G327.

Maroux, S., Louvard, D., Baratti, J., 1973. The aminopeptidase from hog-intestinal brush border. Biochim. Biophys. Acta 321, 282-295.

Metais, P., Bieth, J., 1968. Détermination de l' $\alpha$-amylase par une microtechnique. Ann. Biol. Clin. 26, 133-142.

Nicholson, J.A., Kim, Y.S., 1975. A one-step L-amino acid oxidase assay for intestinal peptide hydrolase activity. Anal. Biochem. 63, 110-117.

Péres, A., Cahu, C.L., Zambonino Infante, J.L., Le Gall, M.M., Quazuguel, P., 1996. Amylase and trypsin responses to intake of dietary carbohydrate and protein depend on the developmental stage in sea bass (Dicentrarchus labrax) larvae. Fish Pysiol. Biochem. 15, 237-242.

Péres, A., Zambonino Infante, J.L., Cahu, C., 1998. Dietary regulation of activities and mRNA levels of trypsin and amylase in sea bass (Dicentrarchus labrax) larvae. Fish Physiol. Biochem. 19, 145-152.

Sheele, G.A., 1993. Regulation of pancreatic gene expression in response to hormones and nutritional substrates. In: Go, V.L.W., Gardner, J.D., Brooks, F.P., Lebenthal, E.P., Di Magno, E.P., Sheele, G.A. (Eds), The Pancreas: Biology, Pathobiology, and Disease. Raven Press, New York, pp.103-120.

Tojo, H., Ono, T., Okamoto, M., 1993. Reverse-phase high-performance liquid chromatographic assay of phospholipases: application of spectrophotometric detection to rat phospholipase A2 isoenzymes. J. Lipid Res. 34, 837-844.

Zambonino Infante, J.L., Cahu, C.L., 1999. High dietary lipid levels enhance digestive tract maturation and improve Dicentrarchus labrax larval development. J. Nutr. 129, 1195-1200.

Zambonino Infante, J.L., Cahu, C.L., Péres, A., 1997. Partial substitution of di- and tripeptides for native proteins in sea bass diet improves Dicentrarchus labrax larval development. J. Nutr. 127, 608-614. 